\title{
Editorial: The Roles of GnIH in Reproductive Function and Behavior
}

\author{
Takayoshi Ubuka ${ }^{1 *}$, Ishwar Parhar', Lance J. Kriegsfeld ${ }^{2}$ and Kazuyoshi Tsutsui ${ }^{3}$ \\ 1 Jeffrey Cheah School of Medicine and Health Sciences, Brain Research Institute Monash Sunway, Monash University \\ Malaysia, Petaling Jaya, Malaysia, ${ }^{2}$ Department of Psychology, Helen Wills Neuroscience Institute, University of California at \\ Berkeley, Berkeley, CA, United States, ${ }^{3}$ Laboratory of Integrative Brain Sciences, Department of Biology, Center for Medical \\ Life Science, Waseda University, Tokyo, Japan
}

Keywords: gonadotropin-inhibitory hormone, RFamide-related peptide, LPXRF-amide peptide family, Reproduction, hypothalamic-pituitary-gonadal axis

\section{Editorial on the Research Topic}

The Roles of GnIH in Reproductive Function and Behavior

Since the discovery of gonadotropin-releasing hormone $(\mathrm{GnRH})$ at the beginning of 1970 s, it has been believed that $\mathrm{GnRH}$ is the only hypothalamic neuropeptide that regulates gonadotropin release in vertebrates. In 2000, however, a novel hypothalamic neuropeptide that actively inhibits gonadotropin release was discovered in quail and termed gonadotropin-inhibitory hormone [GnIH, (1)]. GnIH is one of the RFamide peptides, which is also known as RFamide-related peptide (RFRP) in mammals. Following the discovery, the next 17 years of research revealed that GnIH is highly conserved across vertebrates including humans, and $\mathrm{GnIH}$ is involved in a number of physiological and behavioral functions related to reproduction (2-4). This research topic compiles original research and review articles describing the discovery and progress of GnIH research from leading scientists in the field.

The first review paper by Tsutsui et al. (2) describes how they discovered GnIH from the quail

Edited and Reviewed by: Cunming Duan, University of Michigan, United States

*Correspondence: Takayoshi Ubuka takayoshi.ubuka@monash.edu

Specialty section: This article was submitted to Experimental Endocrinology, a section of the journal

Frontiers in Endocrinology

Received: 03 January 2018 Accepted: 16 January 2018 Published: 31 January 2018

Citation:

Ubuka T, Parhar I, Kriegsfeld LJ and Tsutsui K (2018) Editorial: The Roles

of GnIH in Reproductive

Function and Behavior.

Front. Endocrinol. 9:19. doi: 10.3389/fendo.2018.00019 brain and showed its inhibitory effect on gonadotropin synthesis and release (Tsutsui et al.). They also describe studies over the past decade and a half that established the physiological function of $\mathrm{GnIH}$ as a key player regulating reproduction across vertebrates by acting on the brain and pituitary to modulate their reproductive physiology and behavior. They further introduce recent evidence indicating that $\mathrm{GnIH}$ regulates reproductive behavior through changes in neuroestrogen biosynthesis in the brain (5).

The review by Leon and Tena-Sempere describes their investigations on how GnIH (RFRP) acts centrally to suppress $\mathrm{GnRH} /$ gonadotropin secretion directly or indirectly cooperating with other stimulatory inputs such as kisspeptin in the dynamic regulation of the hypothalamic-pituitarygonadal (HPG) axis. They focus on studies using pharmacological tools and functional genomics in rodent models. In 2006, RF9 was invented as a potent and selective antagonist of neuropeptide FF (NPFF) receptors including GnIH receptor (GPR147), which is also known as NPFF1 (6). TenaSempere's group was the first to show that central administration of RF9 evokes robust luteinizing hormone (LH) secretory responses in rats (7). They were also the first to create an NPFF1 null mouse (8). Although NPFF1 null mouse preserved pubertal progression and fertility, a rapid drop of LH was not observed in NPFF1 null mouse by food deprivation (8) suggesting the role of GnIH in the regulation of feeding (9) and stress (10).

Poling and Kauffman discuss the regulation of GnIH (RFRP-3) neurons by sex steroids and leptin during development and sexual maturation in rodents. They highlight significant changes in GnIH expression and neuronal activation during postnatal and pubertal development and discuss the role of GnIH receptors (GPR147; NPFF1) for normal pubertal timing and developmental LH 
secretion based on their studies (11). Geraghty et al. report their investigation on the role of $\mathrm{GnIH}$ (RFRP) and $\mathrm{GnIH}$ receptor (GPR147; NPFF1) in the regulation of age-related reproductive decline in female rats. Interestingly, females exhibited an increase in GnIH (RFRP) and GPR147 (NPFF1) mRNA expression in the hypothalamus before irregular estrous cycle in middle age rats. This transient increase was followed by subsequent decreases in kisspeptin and GnRH mRNA expression. Expression of GnIH (RFRP) and GPR147 (NPFF1) also increased in the ovaries with advancing age (Geraghty et al.). The results suggest a novel role of GnIH (RFRP) signaling system in the regulation of reproductive cessation.

Reproduction is regulated seasonally in species living in temperate zones and GnIHs (RFRP-1 and -3) are believed to play a critical role in the central control of seasonal reproduction. Henningsen et al. summarize the role and underlying mechanisms of GnIH (RFRP) in the seasonal control of reproduction, primarily focusing on mammalian species. In mammals, the GnIH (RFRP) system is persistently suppressed by short photoperiod and melatonin (12), which is opposite to quail (13). Central chronic administration of GnIH (RFRP-3) in short day-adapted male Syrian hamsters fully reactivates the reproductive axis (14), highlighting the importance of the seasonal changes in GnIH (RFRP) in proper regulation of the reproductive axis. Anjum et al. propose GnIH (RFRP) as a mediator between adiposity and impaired testicular function in their original research article. GnIH (RFRP) treatment increased food intake, upregulation of glucose transporter 4 , and increased uptake of triglycerides in the adipose tissue of mice. On the other hand, treatment with GnIH (RFRP) decreased glucose uptake by downregulation of glucose transporter 8 expression and decreased testosterone synthesis. GnIH (RFRP) treatment also showed decreased expression of insulin receptor in the testis. Their findings suggest a new role of GnIH (RFRP) in fat accumulation, in addition to negative regulation of testosterone synthesis [Anjum et al.; (15)].

\section{REFERENCES}

1. Tsutsui K, Saigoh E, Ukena K, Teranishi H, Fujisawa Y, Kikuchi M, et al. A novel avian hypothalamic peptide inhibiting gonadotropin release. Biochem Biophys Res Commun (2000) 275:661-7. doi:10.1006/bbrc.2000.3350

2. Tsutsui K, Bentley GE, Bedecarrats GT, Osugi T, Ubuka T, Kriegsfeld LJ. Review: Gonadotropin-inhibitory hormone $(\mathrm{GnIH})$ and its control of central and peripheral reproductive function. Front Neuroendocrinol (2010) 31:284-95. doi:10.1016/j.yfrne.2010.03.001

3. Ubuka T, Son YL, Tsutsui K. Molecular, cellular, morphological, physiological and behavioral aspects of gonadotropin-inhibitory hormone. Gen Comp Endocrinol (2016) 227:27-50. doi:10.1016/j.ygcen.2015.09.009

4. Parhar IS, Ogawa S, Ubuka T. Reproductive neuroendocrine pathways of social behavior. Front Endocrinol (Lausanne) (2016) 7:28. doi:10.3389/ fendo.2016.00028

5. Ubuka T, Haraguchi S, Tobari Y, Narihiro M, Ishikawa K, Hayashi T, et al. Hypothalamic inhibition of socio-sexual behaviour by increasing neuroestrogen synthesis. Nat Commun (2014) 5:3061. doi:10.1038/ncomms4061

6. Simonin F, Schmitt M, Laulin JP, Laboureyras E, Jhamandas JH, MacTavish D, et al. RF9, a potent and selective neuropeptide FF receptor antagonist, prevents opioid-induced tolerance associated with hyperalgesia. Proc Natl Acad Sci U S A (2006) 103:466-71. doi:10.1073/pnas.0502090103
Various stressors suppress the HPG axis and consequently induce reproductive dysfunction. Iwasa et al. review the role of GnIH (RFRP) in stress-induced reproductive dysfunction. Psychological and immune stress increase GnIH (RFRP) expression and suppresses $\mathrm{GnRH}$ and gonadotropin secretion $(10,16)$. It was shown that glucocorticoid acts as a mediator of stress and GnIH (RFRP) (17). Soga et al. investigated the effect of earlylife social isolation on serotonergic and GnIH neuronal system using enhanced green fluorescent protein (EGFP)-tagged $\mathrm{GnIH}$ transgenic rats (18) in their research article. They found that the total number of EGFP-GnIH neurons in socially isolated rats was the same as control rats, but c-Fos expression in GnIH neurons was significantly reduced in socially isolated rats. Serotonin fiber juxtapositions on EGFP-GnIH neurons were also reduced in socially isolated rats. Teo et al. found in their original research that socially isolated rats display greater CLOCK expression in the dark phase, while control rats display increased CLOCK expression in the light phase in EGFP-GnIH neurons in the dorsomedial hypothalamus. They also found that $\beta$-catenin expression pattern was disrupted in GnIH cells by social isolation (Teo et al.).

Fish represent more than the half of recognized living vertebrate species. Fish also include model species with scientific, clinical, and economic importance. Muñoz-Cueto et al. summarize all GnIH precursor and peptide sequences identified in fish, distribution of GnIH and GnIH receptor (GPR147; NPFF1) in central and peripheral tissues, physiological actions of $\mathrm{GnIH}$ on the HPG axis, as well as other reported effects of GnIH, and regulatory mechanisms of $\mathrm{GnIH}$ in fish. Finally, Ubuka and Parhar highlight the stimulatory effect of $\mathrm{GnIH}$ in the HPG axis, which was shown in mammals and in fish $(2,3,12,14)$ and investigate their pharmacological and physiological mechanisms as a perspective of future research.

\section{AUTHOR CONTRIBUTIONS}

TU wrote the manuscript. IP, LJK, and KT edited the manuscript.

7. Pineda R, Garcia-Galiano D, Sanchez-Garrido MA, Romero M, Ruiz-Pino F, Aguilar E, et al. Characterization of the potent gonadotropin-releasing activity of RF9, a selective antagonist of RF-amide-related peptides and neuropeptide FF receptors: physiological and pharmacological implications. Endocrinology (2010) 151:1902-13. doi:10.1210/en.2009-1259

8. León S, García-Galiano D, Ruiz-Pino F, Barroso A, Manfredi-Lozano M, Romero-Ruiz A, et al. Physiological roles of gonadotropin-inhibitory hormone signaling in the control of mammalian reproductive axis: studies in the NPFF1 receptor null mouse. Endocrinology (2014) 155:2953-65. doi:10.1210/ en.2014-10308

9. Tsutsui K, Ubuka T. GnIH Control of feeding and reproductive behaviors. Front Endocrinol (Lausanne) (2016) 7:170. doi: 10.3389/fendo.2016.00170

10. Kirby ED, Geraghty AC, Ubuka T, Bentley GE, Kaufer D. Stress increases putative gonadotropin inhibitory hormone and decreases luteinizing hormone in male rats. Proc Natl Acad Sci U S A (2009) 106:11324-9. doi:10.1073/pnas.0901176106

11. Poling MC, Kim J, Dhamija S, Kauffman AS. Development, sex steroid regulation, and phenotypic characterization of RFamide-related peptide (Rfrp) gene expression and RFamide receptors in the mouse hypothalamus. Endocrinology (2012) 153:1827-40. doi:10.1210/en.2011-2049

12. Ubuka T, Inoue K, Fukuda Y, Mizuno T, Ukena K, Kriegsfeld LJ, et al. Identification, expression, and physiological functions of Siberian hamster gonadotropin-inhibitory hormone. Endocrinology (2012) 153:373-85. doi:10.1210/en.2011-1110 
13. Ubuka T, Bentley GE, Ukena K, Wingfield JC, Tsutsui K. Melatonin induces the expression of gonadotropin-inhibitory hormone in the avian brain. Proc Natl Acad Sci U S A (2005) 102:3052-7. doi:10.1073/pnas.0403840102

14. Ancel C, Bentsen AH, Sébert ME, Tena-Sempere M, Mikkelsen JD, Simonneaux V. Stimulatory effect of RFRP-3 on the gonadotrophic axis in the male Syrian hamster: the exception proves the rule. Endocrinology (2012) 153:1352-63. doi:10.1210/en.2011-1622

15. Ubuka T, Ukena K, Sharp PJ, Bentley GE, Tsutsui K. Gonadotropin-inhibitory hormone inhibits gonadal development and maintenance by decreasing gonadotropin synthesis and release in male quail. Endocrinology (2006) 147:1187-94. doi:10.1210/en.2005-1178

16. Iwasa T, Matsuzaki T, Tungalagsuvd A, Munkhzaya M, Kawami T, Niki H, et al. Hypothalamic Kiss1 and RFRP gene expressions are changed by a high dose of lipopolysaccharide in female rats. Horm Behav (2014) 66:309-16. doi:10.1016/j.yhbeh.2014.06.007

17. Son YL, Ubuka T, Narihiro M, Fukuda Y, Hasunuma I, Yamamoto K, et al. Molecular basis for the activation of gonadotropin-inhibitory hormone gene transcription by corticosterone. Endocrinology (2014) 155:1817-26. doi:10.1210/en.2013-2076

18. Soga T, Kitahashi T, Clarke IJ, Parhar IS. Gonadotropin-inhibitory hormone promoter-driven enhanced green fluorescent protein expression decreases during aging in female rats. Endocrinology (2014) 155:1944-55. doi:10.1210/ en.2013-1786

Conflict of Interest Statement: The authors declare that the research was conducted in the absence of any commercial or financial relationships that could be construed as a potential conflict of interest.

Copyright (c) 2018 Ubuka, Parhar, Kriegsfeld and Tsutsui. This is an open-access article distributed under the terms of the Creative Commons Attribution License (CC $B Y)$. The use, distribution or reproduction in other forums is permitted, provided the original author(s) and the copyright owner are credited and that the original publication in this journal is cited, in accordance with accepted academic practice. No use, distribution or reproduction is permitted which does not comply with these terms. 